\title{
Assessment of Nutrient Use Efficiency in Long Term Fertilization on Rice Productivity under Vertisol
}

\author{
Anshita Bajpai $^{1 *}$, Sanjay Dwivedi $^{1}$ and Pragya Pandey ${ }^{2}$ \\ ${ }^{1}$ Department of Agronomy, I.G.K.V., Raipur, (Chhattisgarh), India \\ ${ }^{2}$ Krishi Vigyan Kendra, Bemetara (Chhattisgarh), India \\ *Corresponding author
}

K e y w o r d s
IGKV farm,
integrated nutrient,
RBD

Keywords

IGKV farm, integrated nutrient, RBD

Article Info

Accepted:

Available Online:

\section{A B S T R A C T}

This study was conducted in the year 2017-2018 in IGKV farm Raipur, Chhattisgarh to evaluate the long term impact of integrated nutrient management on productivity of Rice. For this study we calculated the different nutrient use efficiency viz. agronomic efficiency, recovery efficiency. The experiment was conducted with ten Treatments in RBD design with four replication. The result showed that the agronomic efficiency, recovery efficiency and factor productivity index were significantly higher with the $50 \% \mathrm{NPK}+$ Green manuring treatment over all other treatments. While lowest values of above efficiency were recorded with $100 \% \mathrm{~N}$ fertilizer was applied. Physiologic efficiency was recorded highest in 50\% NPK treatment whereas it was at par with $50 \%$ NPK+BGA, $100 \% \mathrm{NPK}+\mathrm{Zinc}$ and $100 \% \mathrm{NPK}+\mathrm{FYM}$ treatment.

\section{Introduction}

Rice (Oryza sativa L.) and wheat (Triticum aestivum L.) crops are major staple foods, contributing a key portion of digestible energy and protein in human intake and occupying a premium position among all food communities. The rice-wheat cropping system (RWCS) is one of the most prominent cropping systems prevailing on the India. Rice is the principal food grain crop of the Chhattisgarh state and occupies about
$66 \%$ of the total cropped area followed by pulses, oilseed and horticulture occupies $17 \%$, $5 \%, 2 \%$ respectively.

Long term Fertilizer experiments are the best tool to assess the influence the continuous application of fertilizers, organic manures used alone or combined on sustainability and soil fertility. To achieve the higher yield of rice, inorganic fertilizers were used with little or no addition of organic manure. Even though the inorganic fertilizers were resulted 
in higher crop yield, over reliance on them associated with declined soil properties and degraded soils by specially organic matter, soil biota and in turn decreased yield in subsequent period. This have also caused environmental hazards such as ground and surface water pollution by nitrate leaching that may deteriorate human and animal health (Piment et al., 1996). Majority of small and marginal farmers do not have financial resources to purchase sufficient fertilizers to replace soil nutrients removed through crop harvests. As a result, soil fertility has declined, and yields of staple food crops are typically low (Sanchez et al., 1997). So to reduce the amount of chemical fertilizers applied the field without resulting in its deficiency will be the main challenge in fertilizer management in the field.

One of the possible options to reduce their use could be recycling of locally available organic wastes, viz. crop residue, green manure and farmyard manure (FYM), which can be a valuable and inexpensive source of plant nutrients. Positive effects of organic wastes on soil structure, aggregate stability andwaterholding capacity have been well documented (Odlare et al., 2008 and Wells et al., 2000). Use of fertilizer, organic inputs and improved germplasm combined with the knowledge on how to adapt these practices to local conditions, aiming at maximizing agronomic use efficiency of the applied nutrients and improving crop productivity (Vanlauwe et al., 2010). We have use farm yard manure (FYM), green manure (GM), blue green algae (BGA) etc. as nutrient sources for Rice.

To find out the most efficient combination of nutrient sources we calculated nutrient use efficiency (NUE like agronomic efficiency, physiological efficiency, recovery efficiency).This observation helped us to find out the amount of dry matter production per unit of nutrient applied or absorbed.

\section{Materials and Methods}

Thus field experiment was conducted Research Farm, College of Agriculture, Indira Gandhi Krishi Vishwavidyalaya, Raipur, Chhattisgarh. Soil was Vertisol in experimental site. Treatment we took for study were $\mathrm{T}_{1}-$ Control, $\mathrm{T}_{2}-50 \%$ of the recommended optimum NPK dose, $\mathrm{T}_{3}-100 \%$ of the recommended optimum NPK dose, $\mathrm{T}_{4}-$ $150 \%$ of the recommended optimum NPK dose, $\mathrm{T}_{5}-100 \%$ of the recommended optimum NPK + ZnSO4@10 kg ha ${ }^{-1}$ in kharif crop only, $\mathrm{T}_{6}-100 \% \mathrm{NP}$ of recommended optimum $\mathrm{N}$ and $\mathrm{P}$ dose, $\mathrm{T}_{7}$ $100 \% \mathrm{~N}$ of recommended optimum $\mathrm{N}$ dose, $\mathrm{T}_{8}-100 \% \mathrm{NPK}+\mathrm{FYM}\left(5 \mathrm{t} \mathrm{ha}^{-1}\right.$ in kharif crop only), $\mathrm{T}_{9}-50 \% \mathrm{NPK}+\mathrm{BGA}\left(10 \mathrm{~kg} \mathrm{ha}^{-1}\right.$ dry culture in kharif crop only), $\mathrm{T}_{10}-50 \% \mathrm{NPK}+$ GM (sown in site and mixed in soil in kharif season only). Different efficiencies were calculated with the help of following formulas:

\section{Agronomic efficiency (AE)}

It refers to the additional produce obtained in $\mathrm{kg}$ grain $\mathrm{kg}^{-1}$ of nutrient applied.

$\mathbf{A E}=\frac{[\text { Grain yield }(\mathrm{kg}) \text { with } \mathrm{N}]-[\text { Grain yield }(\mathrm{kg}) \text { with no } \mathrm{N}]}{\text { Applied } \mathrm{N}(\mathrm{Kg})}$

\section{Physiological efficiency(PE)}

$P E=\frac{\text { Grain yield in } N \text { treated plot }(\mathrm{kg}) \text { - Grain yield in control plot }(\mathrm{kg})}{\text { Total } \mathrm{N} \text { uptake in treated plot }(\mathrm{kg}) \text { - Total } \mathrm{N} \text { uptake in control plot }(\mathrm{kg})}$

\section{Recovery efficiency or apparent nitrogen recovery (ANR)}

Recovery efficiency of nitrogen explains how much $\mathrm{N}$ applied was recovered and taken up by the crop calculated by using the following: 
RE or ANR $=\frac{\mathrm{U}_{\mathrm{N}}-\mathrm{U}_{0}}{\mathrm{~N}}$

Where,

$\mathrm{U}_{\mathrm{N}}=\mathrm{N}$ uptake in $\mathrm{N}$ applied plot, $\mathrm{kg} \mathrm{ha}^{-1}$,

$\mathrm{U}_{0}=\mathrm{N}$ uptake in control plot, $\mathrm{kg} \mathrm{ha}^{-1}$,

$\mathrm{N}=$ Rate of $\mathrm{N}, \mathrm{kg} \mathrm{ha}^{-1}$

\section{Factor productivity index (FPI)}

The factor productivity index of $\mathrm{N}$ explained the yield produced for each $\mathrm{kg}$ of $\mathrm{N}$ applied and it included to the indigenous Soil $\mathrm{N}$ and fertilizer $\mathrm{N}$ was added. It was calculated by using the formula given by Cassman et al., 1996 as follows

$$
\text { Grain yield }\left(\mathrm{kg} \mathrm{ha}^{-1}\right)
$$

$\mathrm{FPI}=$

$$
\mathrm{N} \text { rate }\left(\mathrm{kg} \mathrm{ha}^{-1}\right)
$$

\section{Results and Discussion}

\section{Agronomic efficiency}

The agronomic efficiency (AE), that tells about the additional yield produced for each $\mathrm{kg}$ of $\mathrm{N}$ applied over the control. The effect of continuous application of organic and inorganic fertilizers on agronomy efficiency was found significant (Figure 1 and Table.1).

The $\mathrm{AE}$ of rice ranged from 12 to $58.20 \%$. Highest agronomy efficiency was recorded in $50 \% \mathrm{NPK}+\mathrm{GM}(58.20 \%)$. This was followed by $50 \%$ NPK $(46.40 \%)$ and the lowest agronomy efficiency was recorded in control $\left(\mathrm{T}_{1}\right)$.The findings have been also corroborated with the results of Witt et.al (1999).

Table.1 Effect of long term fertilization and manuring on agronomy efficiency, physiological efficiency, recovery efficiency and factor productivity efficiency in rice $\left(\mathrm{kg} \mathrm{ha}^{-1}\right)$

\begin{tabular}{|l|c|c|c|c|}
\hline Treatments & $\begin{array}{c}\text { Agronomic } \\
\text { efficiency }\end{array}$ & $\begin{array}{c}\text { Physiological } \\
\text { efficiency }\end{array}$ & $\begin{array}{c}\text { Recovery } \\
\text { efficiency }\end{array}$ & $\begin{array}{c}\text { Factor productivity } \\
\text { index }\end{array}$ \\
\hline T1-control & - & - & - & - \\
\hline T2 -50\% NPK & 46.40 & 62.54 & 0.76 & 82.00 \\
\hline T3 -100\% NPK & 30.45 & 48.26 & 0.63 & 48.25 \\
\hline T4 -150\% NPK & 24.17 & 41.49 & 0.59 & 36.03 \\
\hline T5 -100\% +Zn & 29.30 & 56.21 & 0.52 & 47.10 \\
\hline T6 -100\% NP & 29.75 & 51.56 & 0.58 & 47.55 \\
\hline T7 -100\% N & 12.00 & 47.00 & 0.24 & 29.80 \\
\hline T8 -100\% NPK +FYM & 36.10 & 49.21 & 0.74 & 39.45 \\
\hline T9 -50\% NPK +BGA & 43.30 & 61.49 & 0.70 & 78.90 \\
\hline T10 50\% NPK + GM & 58.20 & 47.07 & 1.24 & 93.80 \\
\hline SEm \pm & 3.99 & 3.45 & 0.05 & 3.72 \\
\hline CD(P= 0.05) & 11.95 & 13.21 & 0.17 & 11.17 \\
\hline
\end{tabular}




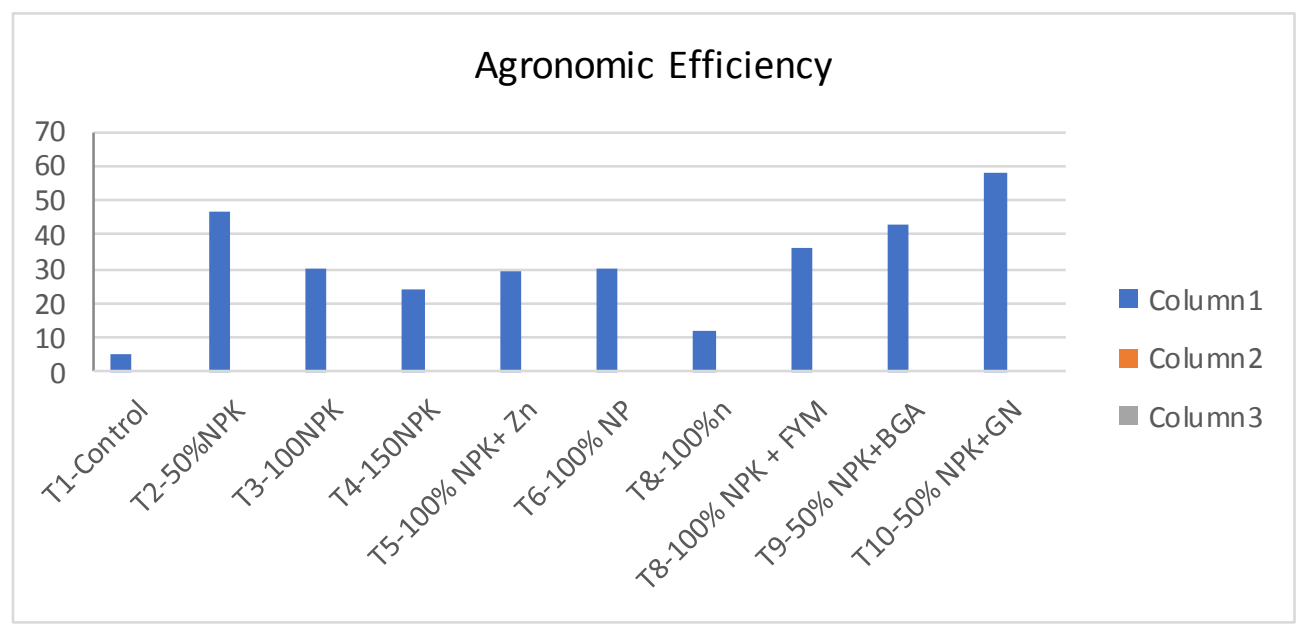

Fig.1 Effect of long term fertilization and manuring on agronomic efficiency

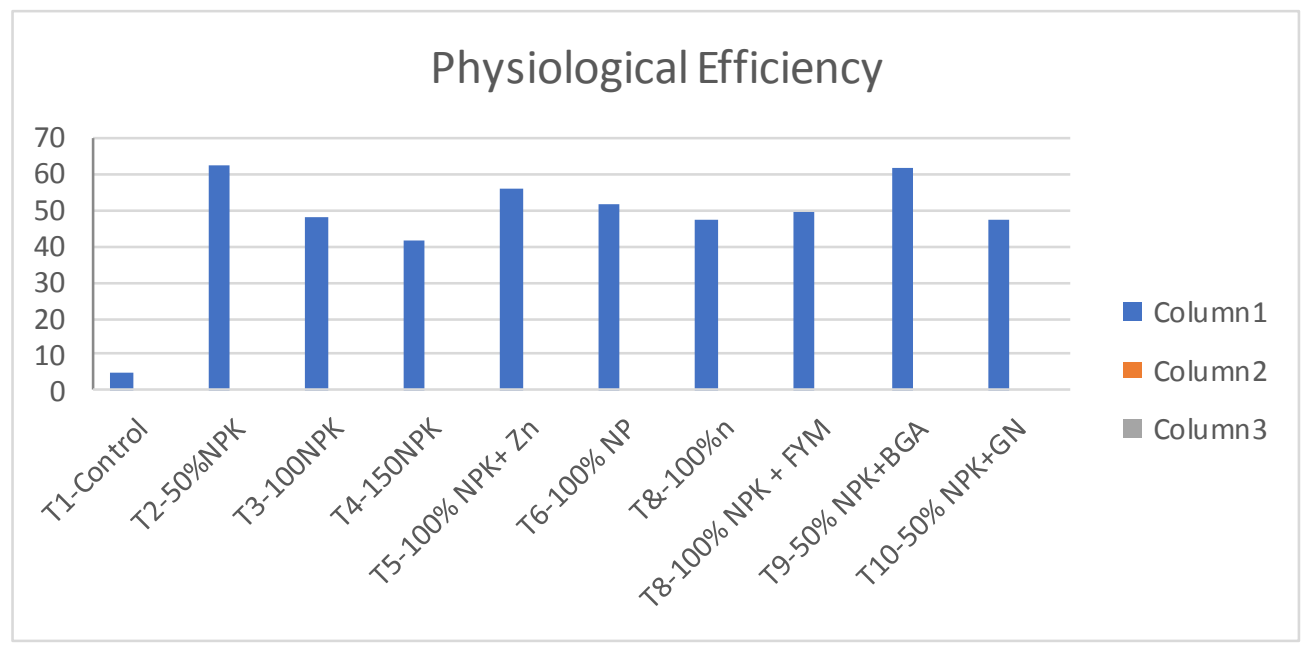

Fig.2 Effect of long term fertilization and manuring on physiological efficiency

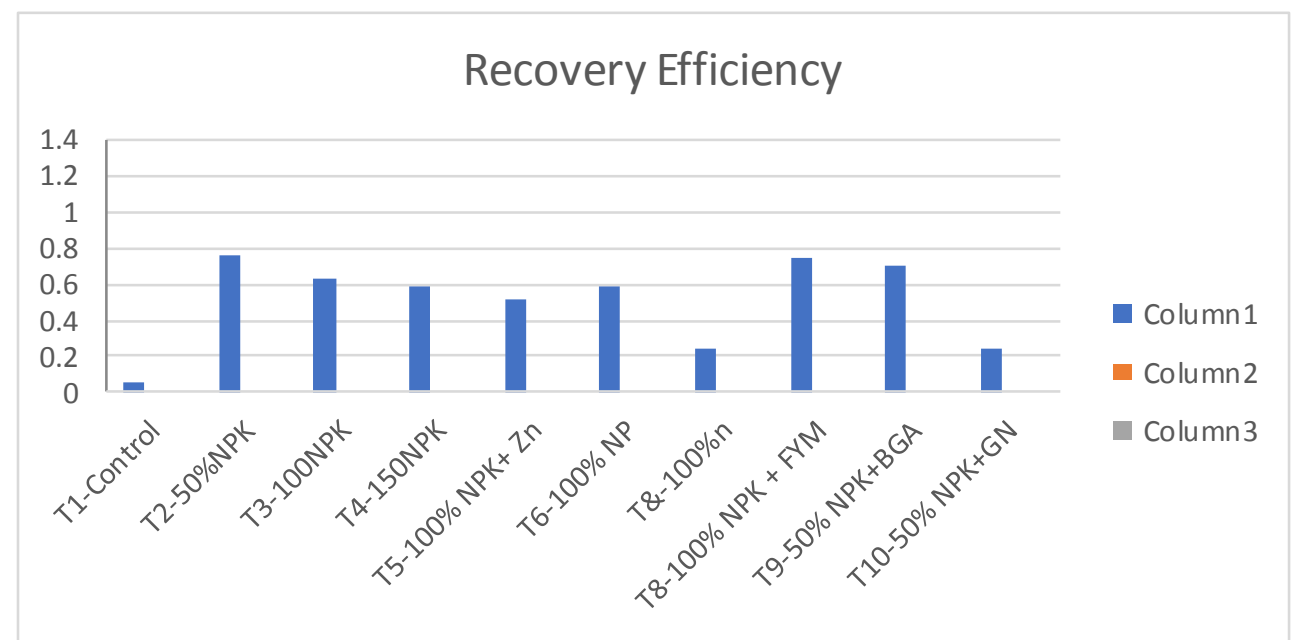

Fig.3 Effect of long term fertilization and manuring on Recovery Efficiency 


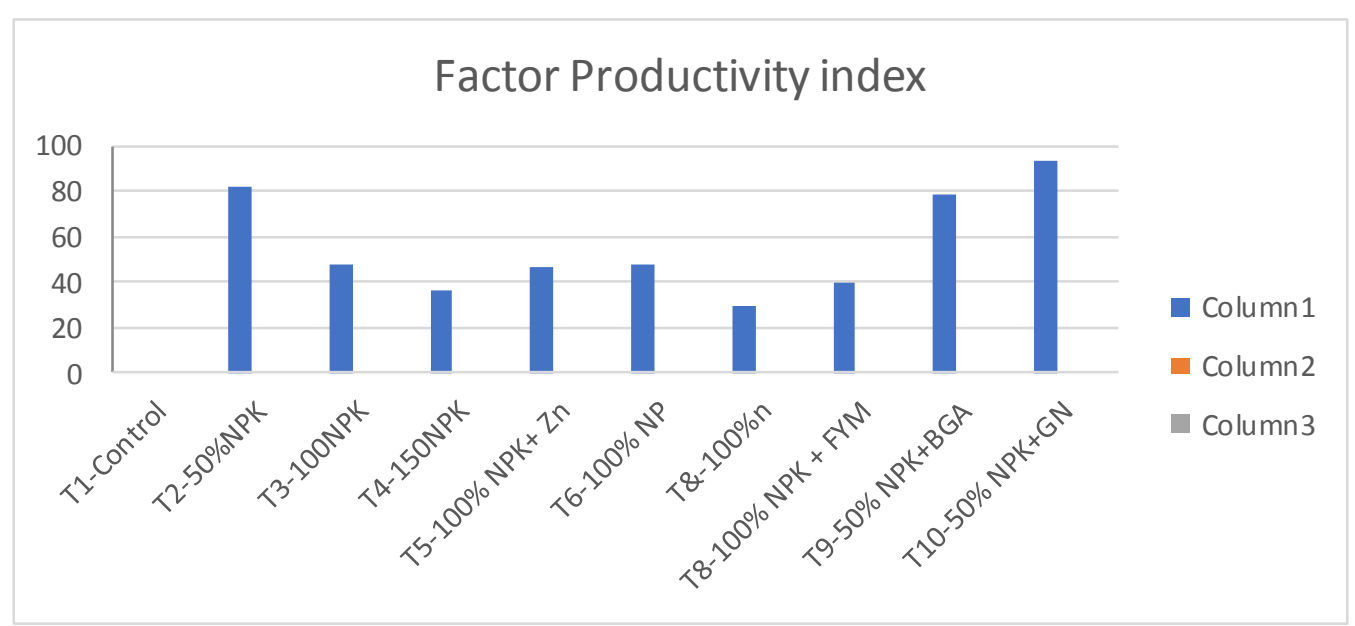

Fig.4 Effect of long term fertilization and manuring on factor productivity index

\section{Physiological efficiency}

The effect of continuous application of organic and inorganic fertilizers on physiological efficiency was found significant (Figure 2 and Table.1). Highest physiological efficiency was recorded from $\mathrm{T}_{2}(50 \% \mathrm{NPK})$. The physiological efficiency of rice was ranged from 47.00 to 62.54 . Lowest of this trait was recorded from $\mathrm{T}_{1}$. This may be due to lower dose of nutrient responses more as compare to higher dose might be linear response of nutrient in lower level as compared to higher doses which are generally gives curvilinear response. The findings have been also corroborated with the results of Surekha et al., (2008).

\section{Recovery efficiency}

The effect of continuous application of organic and inorganic fertilizers on recovery efficiency of $\mathrm{N}$ was found significant (Figure 3 and Table.1). The recovery efficiency was significantly higher with $50 \% \mathrm{NPK}+\mathrm{GM}$ treatment over other treatment. The Treatment $\mathrm{T}_{10}(50 \%$ NPK+ $\mathrm{GM})$ recorded higher recovery efficiency (1.24) followed by $50 \%$ NPK (0.76) and lowest in $100 \% \mathrm{~N}$ treatment (0.24). Similar findings also reported by Roul et al., (2006).

\section{Factor productivity index}

Significant effect of The effect application of long term organic and inorganic fertilizers on Factor productivity index was noticed (Figure 4 and Table.1). 50\% NPK+ GM treatment recorded significantly higher Factor productivity index (93.8) followed by $50 \%$ NPK (82.0) and lowest in 100\% N treatment (29.8). The Factor productivity index of rice was also influenced significantly due to different treatments and the total uptake ranged from 29.8 to 93.8. Similar result corroborated by Surekha et al., (2008).

\section{References}

Cassman, K.G., De Datta, S.K., Amarante, S., Liboon, S., Samson, M.I. and Dizon, M.A. 1996a. Long-term comparison of the agronomic efficiency and residual benefits of organic and inorganic nitrogen sources for tropical lowland rice. Experimental Agric., 32: 427-444.

Odlare, M., Pell, M. and Svensson, K. 2008. Changes in soil chemical and microbiological properties during 4 yearsof application of various organic residues. Waste Management 28:12461253.

Pimentel, D. 1996. Green Revolution and 
chemical hazards. Sci Total Environ, 188: 86-98.

Roul, P.K., Sarawagi, S.K., Shrivastav, S.K. and Kumar, Deepak. 2006. Effect of integrated nitrogen management techniques on productivity, nitrogen uptake, N-use efficiency, economics and energetics of rice (Oryza sativa)Indian mustard (Brassica juncea) sequence. Indian J. Agron. 51 (3): 170173.

Sanchez, P. A., Shepherd, K. D., Soule, M. J., Place, F. M., Buresh, R. J., Izac, A.M., Mokwunye, A. U., Kwesiga,F. R., Ndiritu, C. N. and Woomer, P. L. 1997. Soil fertility replenishment in Africa: an investment in natural resource capital. In Replenishing Soil Fertility in Africa. Soil Science Society of America 51: 146.

Surekha, K., Rao, K.V. and Sam, T.K. 2008. Improving productivity and nitrogen use efficiency through integrated nutrient management in irrigated rice (Oryza sativa L.). Indian Journal of
Agronomy.. 78(2): 173-176..

Vanlauwe, B., Bationo, A., Chianu, J., Giller, K.E., Merckx, R., Mokwunye, U., Ohiokpehai, O., Pypers, P., Tabo, R., Shepherd, K., Smaling, E., Woomer, P.L. and Sanginga, N. 2010. Integrated soil fertility manage-ment: operational definition and consequences for implementation and dissemination. Out Agric., 39:17-24

Wells, A., Chan, K. and Cornish, P. 2000. Comparison of conventional and alternative vegetable farming systems on the properties of a yellow earth in New South Wales. Agriculture, Ecosystems and Environment, 80:47-60

Witt, C., Dobermann, A., Abdulrachman, S., Gines, H. C., Guanghuo, W., Nagarajan, R., Satawatananont, S., Son, T. T., Tan, P. S., Tiem, L. V., Simbahan, G. C. and Olk, D. C., 1999. Internal nutrient efficiencies of irrigated lowland rice in tropical and subtropical Asia. Field Crops Research. 63: 113-138.

\section{How to cite this article:}

Anshita Bajpai, Sanjay Dwivedi and Pragya Pandey. 2020. Assessment of Nutrient Use Efficiency in Long Term Fertilization on Rice Productivity under Vertisol. Int.J.Curr.Microbiol.App.Sci. 9(06): 384-389. doi: https://doi.org/10.20546/ijcmas.2020.906.050 